\title{
Effect of Self-efficacy on the Relationship between Corporal Punishment and School Dropout
}

\author{
Iqbal Ahmad ${ }^{1}$, Hamdan Said ${ }^{1}$, Zubaidah Awang ${ }^{2}$, M. Al-Muz-Zammil Yasin ${ }^{1}$, Zainudin Hassan ${ }^{1} \&$ Syed Shafeq \\ Syed Mansur ${ }^{1}$ \\ ${ }^{1}$ Faculty of Education, Universiti Teknologi Malaysia, Malaysia \\ ${ }^{2}$ Language Academy, Universiti Teknologi Malaysia, Malaysia \\ Correspondence: Iqbal Ahmad, Faculty of Education, Universiti Teknologi Malaysia, Malaysia. E-mail: \\ iqbal_ahmad70@yahoo.com
}

Received: February 8, 2014 Accepted: February 24, 2014 Online Published: February 25, 2014

doi:10.5539/res.v6n1p196 URL: http://dx.doi.org/10.5539/res.v6n1p196

\begin{abstract}
Corporal punishment results in aggressive behaviours in students. As a result, some students leave school. Researchers believe that the issue of school dropout can be reduced by adopting different motivational techniques. Self-efficacy is one technique that can be promoted to create a caring and supportive learning environment. The issue of dropout is alarming in many Pakistani schools especially at the primary level due to the prevalence of corporal punishment and other factors. This issue prevails mostly in government schools where teachers adopt stringent steps in the teaching process. This study was specifically designed to examine the role of self-efficacy as a moderator between corporal punishment and school dropout. Many studies have explored the relations of corporal punishment with school dropout. It remains to be seen what actually moderates these relations. This study contributes to this gap in the literature by examining self-efficacy as an influencing factor. The study used a validated questionnaire to survey 300 government primary school teachers' attitude on this issue. Results of the study indicated that corporal punishment significantly correlated with school dropout rate. Secondly, self-efficacy significantly moderates the relations between corporal punishment and school dropout. On the basis of these findings, the study concludes that teachers may reduce the issue of school dropout by creating a supportive and caring teaching and learning environment in school. Finally, the study suggests that the school administration play a key role to overcome the issue of increasing rate of school dropout by adopting rules and procedures to convince and motivate teachers to avoid corporal punishment.
\end{abstract}

Keywords: corporal punishment, self-efficacy, school dropout, aggressive behavior

\section{Introduction}

Corporal punishment has harmful effecs on students. This is evident in students' behaviour and is exemplified in in the form of decreased self-esteem and self-efficacy, somatic complaints, increased anxiety, negative changes in personality or depression, and school dropout (Greydanus et al., 2003). Corporal punishment is the intentional application of physical pain on an individual which aims to modify his/her undesirable behavior. This includes hitting, slapping, spanking and kicking, shaking or using objects like paddles, belts and sticks (Friedman \& Schonberg, 1996). The use of any type of physical infliction on an individual to change behavior (Straus, 1991) will result in them developing negative attitudes towards learning (Ahmad, Said, \& Khan, 2013). Studies have suggested that educational institutions need to reevaluate their teaching and learning strategies in order to encourage students to achieve better academically (Adibniya, Edar, \& Ebrahimi, 2012). Recent research also highlights the close relationship between students' achievement and their sense of self-efficacy (Ghorbanshirodi, 2012).

Corporal punishment is the use of physical force to cause a child to experience pain or injury for the purpose of correcting or controling a specific undesirable behavior. It is the application of physical force to inflict pain or confinement for an offence or undesirable behavior committed by a student (Cohen, 1994; Baumrind, 1996). Despite a complete ban on corporal punishment by law around the world, there have been some reported acts of corporal punishment by teachers in different parts of the world. There are mixed research findings. For example in Australia, despite a complete ban on the use of corporal punishment, teachers still support the application of corporal punishment to discipline and control behavior (Richards, 2003). Advocates of corporal punishment in 
schools generally contend that it is an effective form of correcting child misbehavior (Flynn, 1994). Teachers think that corporal punishment is the only way to improve desirable behavior of students in schools. Many teachers still consider corporal punishment necessary for positive behavior modification of children in schools. In this regard, most of the teachers use a cane as a means to discipline students (Boser, 2001). Similarly, a survey in America showed that sixty five percent of Americans support use of the cane and spanking. Twenty six percent of the respondents said that school teachers should be allowed to use the cane freely to control behaviors of students who create discipline problems and disturbance during the teaching and learning process (Vally, 1998).

Southern Africans also support the use of corporal punishment with $81.1 \%$ in favor of using the cane and spanking children for ill discipline in schools (Roussow, 2003). In Pakistan, the prevalence of corporal punishment has existed for many years. This is one of the main reasons for truancy and student dropout. However, in recent years the government has taken efforts to ban corporal punishment in schools. It is observed that while teachers support the ban, there are still some teachers who think that they should not be stopped from using corporal punishment. These teachers think that it is an essential necessity and is a means to control criminal or unwanted student behaviour in schools (Iqbal, 2003).

Corporal punishment results in more aggressive behaviors among students. As a result, they leave school. This trend is found to be more prevalent in early schooling. Despite this, teachers believe that corporal punishment is necessary for ensuring desirable behavior in children. They consider it an infringement of teachers' rights to be told not to punish students. In some parts of the world, corporal punishment is even desired by parents who fully endorse the use of canes in schools to discipline children. Like the teachers, these parents also believe that corporal punishment is necessary to better educate a child. Through their combined beliefs, they justify the use of corporal punishment in order to maintain discipline in schools (Tharps, 2003). Many teachers believe that without corporal punishment there will be behavioral problems and the situation in the classrooms will be out of control (Straus, 1991). Despite this feeling by one group of teachers, there are numerous examples of teachers who consider corporal punishment a harmful exercise for students (Gershoff, 2002). For example, Roos (2003) found that some teachers think that one of the evident effects of corporal punishment is the growing rate of student dropout from schools. Majority of the students in the developing world hardly reach secondary education due to dropout. This trend prevails at the primary level where children are punished physically by teachers. As a result, students either do not come to school or run out of school due to the fear of physical pain inflicted on them (Gunnoe \& Mariner, 1997). In addition, corporal punishment produces harmful effects in children such as somatic complaints, increased anxiety, and negative changes in personality or depression and school dropout (Straus, 2003).

Corporal punishment is a form of maltreatment and social abuse of students. There is a strong correlation between corporal punishment and negative psychological consequences on students. It creates extreme psychological complexities in students which in turn lead to increased rates in school dropouts. It also develops an illness among students called Educationally Induced Post-Traumatic Stress Disorder (EIPSD) (Gunnoe \& Mariner, 1997; Tafa, 2002). Corporal punishment indirectly encourages children to learn new ways and use of violence because they see their teachers using different methods of punishment at school (Brezina, 1999). Corporal punishment causes serious mental deficiency, mild or severe depression, abnormal physical complaints, psychological and social complications among students which lead to truancy in schools, reduced mental activities, low motivation, increased reactionary attitude, loss of confidence, intolerance, dropouts, lack of trust and also severe personality disorders. Depression further causes other complications such as social isolation, suicide and so on (Rice, 1987; Sarasoun \& Najarain as cited in Maddahi et al., 2012). The use of corporal punishment to discipline students may result in them to be silenced or forced to conform to the standards but ultimately these students will develop resentment towards the rules and the system. As a result they show deviant behaviors and may also become problematic individuals later in life (Kaur, 2005). Based on the above literature review, the researchers developed the following research framework to be used for this study.

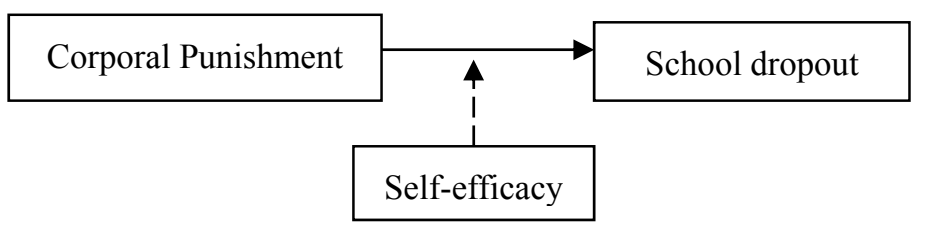

Figure 1. Research model 


\section{Research Objectives}

The objectives of this study are:

1. To examine the relationship between corporal punishment and school dropout.

2. To assess the moderating effect of self-efficacy on the relationship between corporal punishment and school dropout.

\section{Research Questions}

This study attempted to answer the following research questions:

1. What is the relationship between corporal punishment and school dropout?

2. Does self-efficacy moderate the relationship between corporal punishment and school dropout?

\section{Hypotheses}

Based on the literature, the following alternative hypotheses are formulated for this study.

1. There is a positive relationship between corporal punishment and school dropout.

2. Self-efficacy moderates the relationship between corporal punishment and school dropout.

\section{Methodology}

Using a correlation design, this study surveyed attitudes of 300 government primary school teachers in Peshawar division of Khyber Pakhtukhwa, Pakistan (KPK). Simple random sampling technique was applied to select sample for this study. For this purpose, the researchers used Fish Bowl method of sampling. A Five Point Likert Scale (1 - strongly disagree to 5 - strongly agree) questionnaire was used to collect data from the respondents. Data was analyzed using Statistical Package for Social Sciences (SPSS) Pearson Correlation Coefficient was used to measure the relationship between the independent and dependent variables and hierarchical Multiple Regression Analysis (HMRA) was used to measure the moderating effect of self-efficacy on the relationship between the independent and dependent variables.

\section{Data Analysis}

The purpose of this study was to examine the effect of corporal punishment on school dropout in government primary schools in Peshawar division of KPK. Analysis of the data is presented in Tables 1, 2, and 3 followed by findings and conclusions.

\section{Correlation Analysis}

Correlation analysis was conducted to examine the relationship between independent variable (corporal punishment) and dependent variable (school dropout) of students.

Table 1. Correlation analysis of corporal punishment and school dropout

\begin{tabular}{lcc}
\hline Variables & School dropout & Corporal punishment \\
\hline School dropout & 1 & \\
Corporal punishment & $0.54^{*}$ & 1 \\
\hline *Correlation is significant at the 0.01 level (2-tailed). &
\end{tabular}

Table 1 shows that corporal punishment is significantly positively correlated with school dropout and significant at $\mathrm{p}$ value of 0.01 .

\section{Regression Analysis}

Regression analysis was measured by testing the research hypotheses. The results for each variable are discussed below.

$\mathrm{H}_{1}$ : There is a positive relationship between corporal punishment and school dropout

Table 2. Regression analysis of corporal punishment and school dropout

\begin{tabular}{lccccc}
\hline Variables & R square & t-value & Coefficient & F-value & P value \\
\hline Corporal Punishment & 0.774 & 14.33 & 0.75 & 289.0 & 0.00 \\
\hline
\end{tabular}


In Table 2, the value of coefficient beta is 0.75 which shows a significantly positive relationship between corporal punishment and school dropout. The R-square value of 0.774 shows that there is a $77.4 \%$ variation in the dependant variable (corporal punishment) as explained by the independent variable (school dropout). The model's goodness of fit is shown by F-value that is 289.0. Hence, $\mathrm{H}_{1}$ was accepted and it proves that corporal punishment is significantly positively correlated with school dropout.

\section{Descriptive Analysis}

Table 3 shows the correlation analysis and descriptive statistics for the three variables. The correlation coefficients values are less than 0.90 which show that the data is not affected by serious co-linearity problem.

Table 3. Moderating effect of self-efficacy on corporal punishment and school dropout

\begin{tabular}{clcccccc}
\hline No & Variables & $\mathrm{N}$ & Maximum & Minimum & Mean & Standard Deviation & Variance \\
\hline 1 & Corporal punishment & 300 & 4.34 & 2.29 & 3.51 & 0.458 & 0.210 \\
2 & Self-efficacy & 300 & 4.65 & 1.38 & 3.41 & 0.626 & 0.393 \\
2 & School dropout & 300 & 1.83 & 4.67 & 3.4 & 0.626 & 0.393 \\
\hline
\end{tabular}

As shown in Table 3, the interaction of self-efficacy is significantly associated with corporal punishment and school dropout. To test the moderating effect of self-efficacy on the relationship between corporal punishment and school dropout, we first created interaction terms by multiplying corporal punishment with self-efficacy.

\section{Findings and Discussion}

The purpose of this study was to investigate the correlation between corporal punishment and school dropout. The study further aimed to examine the moderating effect of self-efficacy on the relationship between corporal punishment and school dropout. The study found a significantly positive correlation between corporal punishment and school dropout. It can be inferred from this finding that corporal punishment is a major reason for the growing dropout rate in primary schools in Peshawar division of KPK. This finding also supports the findings of previous studies that corporal punishment results in more aggressive behaviors among students which result in them leaving school (Tharps, 2003). The study also found that self-efficacy significantly moderates the relationship between corporal punishment and school dropout. It can thus be inferred from this finding that if students are encouraged to participate in the process of learning, it leads to the development of positive confidence among them.

\section{Conclusion}

Based on the correlation analysis, it can be concluded that there is a strong correlation between corporal punishment and student dropout. The study provides an insight on corporal punishment as one of the causes that leads students to dropout from school. This study also concludes that self-efficacy strongly moderates the relationship between corporal punishment and school dropout. This finding supports the logic that physical torture promotes fear among students and compels them to either run away or to abstain from going to school. This study, hence, concludes and suggests that if teachers avoid punishment and develop a culture of respect, it may result in students to be more motivated and also see a decline in school dropout rate.

\section{References}

Ahmad, I., Said, H., \& Khan, F. (2013). Effect of corporal punishment on students' motivation and classroom learning. Review of European Studies, 5(4), 130-134. http://dx.doi.org/10.5539/res.v5n4p130

Adibniya, A., Edar, N., \& Ebrahimi, S. (2012). The comparison of the effect of the modular teaching method and problem-solving method on academic achievement of the students in natural science. Journal of Basic and Applied Sciences Research, 2(2), 1511-1521.

Baumrind, D. (1996). A blanket injunction against disciplinary use of spanking is not warranted by the data. Pediatrics, 98(4), 828-831.

Boser, U. (2001). The unsparing rod: Schools are still fighting the right to paddle. U.S. News and World Report: Washington.

Brezina, T. (1999). Teenage violence towards parents as an adaptation to family. Youth and Society, 30, 416-444. http://dx.doi.org/10.1177/0044118X99030004002 
Cohen, S. (1996). Teachers and pupils attitudes and practices regarding the abolition of corporal punishment in schools in the Gauteng Area. Unpublished Masters Research. Conventions on the Rights of the Child.

Flynn, C. P. (1994). Regional differences in attitudes toward corporal punishment. Journal of Marriage and Family, 56, 330-344. http://dx.doi.org/10.2307/353102

Friedman, S. B., \& Schonberg, S. K. (1996). The short- and long- term consequences of corporal punishment. Pediatrics, 98, 803-860.

Gershoff, E. T. (2002). Corporal punishment by parents and associated child behaviors and experiences: A Meta-analytic and theoretical review. Psychological Bulletin, 124(4), 539-579. http://dx.doi.org/10.1037/0033-2909.128.4.539

Ghorbanshirodi, S. (2012). The relationship between self-esteem and emotional intelligence with imposter Ssyndrome among medical students of Guilan and Heratsi universities. Journal of Basic and Applied Sciences Research, 2(2), 1793-1802.

Greydanus, D. E., Pratt, H. D., Spates, C. R., Blake-Dreher, A. E., Greydanus-Gearhart, M. A., \& Patel, D. R. (2003). Corporal punishment in schools: Position paper of the Society for Adolescent Medicine. Journal of Adolescent Health, 32(5), 385-393. http://dx.doi.org/10.1016/S1054-139X(03)00042-9

Gunnoe, M. L., \& Mariner, C. L. (1997). Towards a developmental-contextual model of the effects of parental spanking on children's aggression. Archives of Pediatric and Adolescent Medicine, 151(8), 768-775. http://dx.doi.org/10.1001/archpedi.1997.02170450018003

Iqbal, N. (2003). Rights-Pakistan: Call to spare the rod in schools grows louder. New York: Global Information Network.

Kaur, S. (2005). Wounded innocence. The Tribune (Spectrum), 9, October, 1.

Maddahi, E. M., Khalatbari, J., Mobarhan, Z. G., Samadzadeh, M., Keikhayfarzaneh, M. M., \& Javidi, N. (2012). The study of dialectical behavior therapy efficacy on the amount of high school student's depression and suicide thoughts in Rasht City, Iran. Journal of Basic and Applied Scientific Research, 2(1), 466-470.

Rice, J. E. (1987). The attitudes of teachers towards corporal punishment. Unpublished Master of Education Dissertation. University of South Africa.

Richards, P. (2003). Education-Trinidad: Support for corporal punishment grows. New York: Global Information Network.

Roos, R. (2003). Legal requirements for school rules and disciplinary sanctions. Koers, 68(4), $481-498$. http://dx.doi.org/10.4102/koers.v68i4.353

Roussow, J. P. (2003). Learner discipline in South African public schools - A qualitative study. Koers, 68(4), 413-435.

Straus, M. A. (2003). The primordial violence: Corporal punishment by parents, cognitive development, and crime. Walnut Creek CA: Alta Mira Press.

Straus, M. A. (1991). Discipline and deviance: Physical punishment of children and violence and other crime in adulthood. Social Problems, 38, 133-154. http://dx.doi.org/10.2307/800524

Tafa, E. M. (2002). Corporal punishment: The brutal face of Botswana's authoritarian schools. Education Review, 54(1), 17-26. http://dx.doi.org/10.1080/00131910120110848

Tharps, L. L. (2003). The truth about spanking. Essence, 33(1), 22-30.

Vally. S. (1998). Spare the child and spoil the rod. Educators Voice, 2(8). Retrieved from http:/education.qld.gov.au/corporate/professional_exchange/edhistory/edhistopics/corporal/union.html

\section{Copyrights}

Copyright for this article is retained by the author(s), with first publication rights granted to the journal.

This is an open-access article distributed under the terms and conditions of the Creative Commons Attribution license (http://creativecommons.org/licenses/by/3.0/). 